\title{
Effect of Mulching on Growth and Productivity of Bt Cotton (Gossypium hirsutum L.)
}

\author{
Khushdeep Singh, Balwinder Singh Dhillon* and Vikram Limba
}

College of Agriculture, Guru Kashi University, Talwandi Sabo, Punjab, India

*Corresponding author

\section{A B S T R A C T}

\begin{tabular}{|l|}
\hline Ke y w o r d s \\
Boll weight, Bt \\
cotton, Hand \\
hoeing, Mulching, \\
Seed cotton yield
\end{tabular}

\section{Introduction}

American cotton (Gossypium hirsutum L.) is an important fibre crop of global significance and cultivated in tropical and subtropical regions of more than seventy countries in the world of which the top five producers are China, USA, India, Pakistan and Uzbekistan. It is a cash crop of India and the most important foreign exchange earner through export of raw cotton, garments and cotton seed by products in the form of edible oils and oilcakes. It plays a key role in national economy in terms of both employment generation and foreign exchange earnings. Cotton impacts the lives of estimated 60 million people in India. The area under cotton in India was 122.4 lakh ha with an annual production of 361 lakh bales ( 1 bale $=170 \mathrm{~kg}$ ) and the productivity was $501.5 \mathrm{~kg}$ lint $\mathrm{ha}^{-1}$. It is grown in almost all the states but Gujarat, Maharashtra, Andhra Pradesh, Madhya Pradesh, Punjab, Haryana, Karnataka, Rajasthan and Tamil Nadu contribute major in area and production. In Punjab, cotton is a crop of great economic value, playing a significant role in the socio economic status of the farmers. It occupies an area of about 2.8 lakh ha with an annual production of 11.5 lakh bales and the productivity was $688.4 \mathrm{~kg}$ lint ha- (Anonymous 2019). 
The existing cotton genotypes are prone to infestation by a variety of insect-pests especially bollworms. Between independence and the year 2000, the cotton cultivars have been changed from varieties to hybrids and the suitable agronomy of these hybrids has been developed. The transgenic cotton era has dawned in our country with the approval accorded by Genetic Engineering Approval Committee, Govt. of India for the commercial cultivation of $\mathrm{Bt}$ cotton hybrids in the southern and central zones from 2002 crop season onwards. Cry 1 Ac gene of Bacillus thuringiensis, which has the capacity to produce proteins toxic to lepidopteron pests in general, has been introduced in cotton, conferring inbuilt resistance (Perlak et al., 1990). These Bt cotton not only give higher yields, but also higher net income over traditional cottons due to reduced plant protection costs. Till now more than 20 hybrids have been approved for commercial cultivation by Genetic Engineering Approval Committee.

Mulching is a common practice to cover soil surface and it not only conserves moisture but also moderates temperature besides effectively controlling the weeds. It creates congenial conditions for the growth and ameliorates various environmental stresses (Macilwain, 2004). It exerts decisive effects on earliness, yield and quality of the crop. Straw mulching has a major effect on soil water and thermal regimes. The mulch probably acts as an insulator, resulting in smaller fluctuations in soil temperature in mulched treatments as compared to without mulch.

Mulches can be more effective under extreme weather conditions as compared to normal conditions. Mulching is a common practice recommended for tropical small farming holder, due to its ability to conserve soil and moisture and also suppress weeds (Sah 2015).
Mulching increased soil moisture content, improved the soil structure and decreased the weed growth, and thereby enhanced yield in crops (Govindappa 2014). Weeds compete for nutrients, water, light and thus reduce the yield of cotton substantially. Weeds are responsible for losses in cotton yield to an extent of 34-61.4\% (Ahmad 2003). Although a number of methods and techniques are used for weed control, still cotton yield is reduced significantly by weeds infestation (Ashok et al., 1974). Mulching is the practice of covering the soil surface to make favorable conditions for plant growth and development. The main objective of mulching is water saving and weed control. Mulches when spread over the soil surface, minimize the water runoff, increase infiltration, provide shade to the soil (suppress weeds) and act as barrier to reduce water loss in form of vapors (Lamont, 2005).

Hand hoeing are the oldest methods of weed control. Although they are labor intensive and often relatively ineffective for the control of perennial weeds, they typically cause minimal environmental impact. The field is subjected to drying to avoid re-establishing of uprooting weeds followed by a copious irrigation. Thought it is costly if a considered useful because it improves soil physical condition in addition to the removal of weeds. By periodical hoeing, difficult weeds can easy removed. Main advantages of hoeing can be quick and easy in the right conditions (dry) and does not bring up too many dormant seeds deeper down. This kind of weeding is more is more easily done between rows of crops. However meager information is available on effect of wheat straw application and hand hoeing on seed yield of Bt cotton in South-western part of Punjab. Therefore, there is need to adapt ways and means to manage this particular valuable resource particular wheat straw and hand hoeing in cotton. 


\section{Materials and Methods}

The present investigation entitled "Effect of mulching on growth and productivity of $\mathrm{Bt}$ cotton (Gossypium hirsutum L.)\| was conducted at Guru Kashi University, Talwandi Sabo (Bathinda). It is situated between $29.990 \mathrm{~N}$ latitude and $75.080 \mathrm{E}$ longitude with an altitude of 252 meters above the mean sea level. The experimental site belongs to sub-tropical semi-arid climate having extreme winters and summers.

The experimental site belongs to semi-arid climate, where both summers and winters are acute. A maximum temperature of about $45^{\circ}$ is very common during summer, while freezing temperature accompany by frost happening may be in the months of December and January. The monsoon season normally starts from the first week of July. However, a few showers received during winter season also. The temperature and rainfall both were found to be optimum for cotton crop.

The soil was slightly alkaline $(\mathrm{pH} 8.65)$ with normal electrical conductivity $\left(0.20 \mathrm{dSm}^{-1}\right)$. The soil was medium in organic carbon content $(0.16 \%)$. The available nitrogen $\left(178.3 \mathrm{~kg} \mathrm{ha}^{-1}\right)$ was low, whereas the available phosphorus (15.8 kg ha $\left.{ }^{-1}\right)$ and available potassium $\left(176.3 \mathrm{~kg} \mathrm{ha}^{-1}\right)$ were both medium. The experiment was laid out in Randomized complete block design with four replications. The treatments comprised of five levels (Control (no wheat straw), Hand hoeing, Wheat straw mulching @ $5 \mathrm{t} / \mathrm{ha}$, Wheat straw mulching@10t/ha, Wheat straw mulching @ $15 \mathrm{t} / \mathrm{ha})$.

The plant height was measured from each plot of the five different tagged plants at the time of maturity. It was taken from the base of the plant at ground level to the tip of plant and expressed as average plant height in $\mathrm{cm}$.
Dry matter accumulation was recorded from each plot, one plant was selected at random from a row ear marked for destructive sampling was uprooted and different plant parts viz. stem and leaves were separated. These samples were first air-dried and then oven dried to constant weight at $65^{\circ} \mathrm{C}$ in hot air oven and their by weight was recorded. The leaf area index was recorded at maturity. The observations were recorded from each plot and the area of each leaf blade was calculated by using the formula.

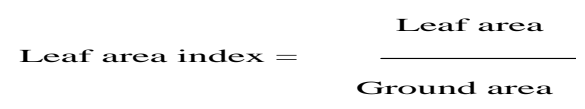

The average value was recorded as Number of sympodial branches/plants The flower bearing branches were counted from the five selected plant, which bear flowers at each node and average number of sympodial branches/plant was calculated. Seed cotton and stalk yield.

The total seed cotton was harvested in two pickings. The seed cotton picking from net plot was weighed separately. The sum of seed cotton per plot picked at different pickings was used for working out seed cotton yield/hectare. The total weight of crop biomass from each plot was weighed separately and stalk yield in $\mathrm{kg} / \mathrm{plot}$ was calculated and converted it into $\mathrm{q} / \mathrm{ha}$.

\section{Results and Discussion}

\section{Growth parameters of Bt cotton}

The data pertaining to plant height indicated that plant height was influenced significantly with application of wheat straw as mulching. The surface application of wheat straw mulching @ 10 t/ha recorded highest plant height $(146.5 \mathrm{~cm})$ which was significantly higher than other treatments. The minimum plant height $(129.9 \mathrm{~cm})$ was recorded in control. The increase in plant height may be 
due to proper soil moisture availability and more nutrient uptake by the plant which make favorable environment for better growth and development of plant.

The data indicated that dry matter was influenced significantly with application of wheat straw as mulching. The surface application of straw mulching @ 15 t/ha recorded highest dry matter (30.9 q/ha) which was significantly higher than other treatments, being at par with wheat straw @ 10 t/ha. The minimum dry matter $(19.5 \mathrm{q} / \mathrm{ha})$ was recorded in control. The increase in dry matter might be due to proper soil moisture availability and more nutrient uptake by the plant which make favorable environment for better growth and development of plant.

Leaf area index (LAI) denotes the size of assimilatory surface of plant stand and is defined as leaf area per unit ground area. It is an important growth character which is directly related to photosynthetic processes, weeds suppression and proper canopy development and determine crop yield.

The data revealed that wheat straw application significantly increased leaf area index as compared to control. The maximum leaf area index (2.73) of cotton was recorded with application of wheat straw @ 10 t/ha. The minimum leaf area index was recorded in control plots (2.12).

Table.1 Effect of different levels of wheat straw mulching on growth parameters of Bt cotton

\begin{tabular}{|c|c|c|c|}
\hline Treatment & $\begin{array}{c}\text { Plant height } \\
(\mathbf{c m})\end{array}$ & $\begin{array}{c}\text { Dry matter } \\
\text { accumulation } \mathbf{( q / h a )}\end{array}$ & Leaf area index \\
\hline Control & 129.9 & 19.5 & 2.12 \\
\hline Hand hoeing & 134.5 & 21.1 & 2.19 \\
\hline $\begin{array}{c}\text { Wheat straw mulching } \\
\text { @ 5 t/ha }\end{array}$ & 136.3 & 27.3 & 2.31 \\
\hline $\begin{array}{c}\text { Wheat straw mulching } \\
\text { @ 10 t/ha }\end{array}$ & 146.5 & 28.4 & 2.73 \\
\hline $\begin{array}{c}\text { Wheat straw mulching } \\
\text { @ 15 t/ha }\end{array}$ & 140.1 & 30.9 & 2.43 \\
\hline LSD (P=0.05) & 0.6 & 2.9 & 0.04 \\
\hline
\end{tabular}

Table.2 Effect of different levels of wheat straw mulching on yield attributes of Bt cotton

\begin{tabular}{|c|c|c|c|}
\hline Treatment & $\begin{array}{c}\text { Number of } \\
\text { branches/plant }\end{array}$ & $\begin{array}{c}\text { Seed cotton } \\
\text { yield(kg/ha) }\end{array}$ & $\begin{array}{c}\text { Stalk } \\
\text { yield (kg/ha) }\end{array}$ \\
\hline Control & 18.1 & 2420 & 3164 \\
\hline Hand hoeing & 18.9 & 2505 & 3713 \\
\hline $\begin{array}{c}\text { Wheat straw mulching } \\
\text { @ 5 t/ha }\end{array}$ & 20.5 & 2885 & 4189 \\
\hline $\begin{array}{c}\text { Wheat straw mulching } \\
\text { @ 10 t/ha }\end{array}$ & 25.1 & 3350 & 5285 \\
\hline $\begin{array}{c}\text { Wheat straw mulching } \\
\text { @ 15 t/ha }\end{array}$ & 23.1 & 3252 & 4305 \\
\hline LSD (P=0.05) & 4.5 & 353 & 450 \\
\hline
\end{tabular}




\section{Yield attributes of Bt cotton}

The data pertaining to number of branches/plant indicated that number of branches/plant was influenced significantly with application of wheat straw as compared to control. The surface application of wheat straw@10 t/ha significantly increased plant branches (25.1) as compared to other treatments. The minimum number of branches/plant (18.1) was recorded in 25 control. The increase in number of branches/plant may be due to proper soil moisture availability and more nutrient uptake by the plant which make favorable environment for better plant branches and development of plant.

The data indicated that the seed cotton yield influenced by the mulch application. The higher seed cotton yield was recorded with the application of wheat straw mulching @ 10 t/ha which was significantly higher over the control, hand hoeing, wheat straw mulching @ $5 \mathrm{t} / \mathrm{ha}$ and it was statistically at par with wheat straw mulching @ 15 t/ha. With application of mulching @ 5,10 and 15 t/ha recorded 19.2, 38.4 and $34.4 \%$ more seed cotton yield than control. The increase in yield was obtained up to $10 \mathrm{t} / \mathrm{ha}$ wheat straw application but there was decrease in yield with further increase in rate of wheat straw application although increase was higher than control. Seed cotton yields of control and hand hoeing was also statistically at par with each other. The data further showed that application of $10 \mathrm{t} / \mathrm{ha}$ wheat straw gave (3350 $\mathrm{kg} / \mathrm{ha}$ ) higher seed cotton yield over control. Better channelization of photosynthates under mulched treatment is supported by higher number of bolls/plant and significantly higher boll weight than the unmulched treatment. The differences in plant height, leaf area index and dry matter were significant under mulch treatment in comparison to unmulched treatment. Similarly, though the number of bolls were a bit higher under unmulched treatment than mulched treatment but it seems that boll development were better under mulched treatment as is indicated by higher number of seeds/pod and significantly higher seed cotton yield under this treatment when compared with unmulched treatment. Another point which needs elaboration here is that how wheat straw mulch could have helped the crop to yield higher than under no mulch treatment and that too under limited moisture condition during the kharif season. The increase in grain yield as compared to control may be attributed due to increase in plant height, primary branches, number of bolls/plant.

The data revealed that stalk yield increased significantly with the application of wheat straw as compared to control. The highest stalk yield $(5285 \mathrm{~kg} / \mathrm{ha})$ was recorded with 10 t/ha wheat straw application, which was significantly higher than other treatments. The increase in stalk yield was upto $10 \mathrm{t} / \mathrm{ha}$ wheat straw application and decreased thereafter although it was higher than control. The minimum stalk yield was recorded in control where no wheat straw was applied. The increase in stalk yield of cotton may be attributed due to higher plant growth as well as other yield contributing characters. The lowest stalk yield $(3164 \mathrm{~kg} / \mathrm{ha})$ was recorded in control.

\section{References}

Anonymous (2019) Cotton Advisory Board, https://www.caionline.in/articles/cotton advisory-board-cab-pegs-2018-19cotton-crop-at-36-1-mln-bales.

Ahmed Z I, Ansar M, Iqbal M and Minhas N $M(2003)$ Effect of planting geometry an mulching on moisture conservation, weed control and wheat growth under rainfed conditions. Pak J Bot 39: 11891195. 
Ashok D A (1974) Effect of polyethylene and paddy straw mulches on the moisture utilization, growth and yields of pulses. Tech Bull, University of Agricultural Sciences, Bangalore, India.

Govindappa M and Pallavi C S (2014) Importance of mulching as a soil and water conservative practice in fruit and vegetable production-review. Int J Agric Innov Res 3(4): 1014-1017.

Lamont W. J. 2005. Plastics: Modifying the microclimate for the production of vegetable crops. Horticulture Technology. 15: 477-481.

Macilwain C (2004) Is Organic farming better for the environment? Nature 428: 797798.

Sah D, Dubey R K, Singh V, Debnath P and Pandey A K (2015) Study of weed management practices on growth, root nodulation and yield components of vegetable cowpea (Vigna unguiculata). The Bioscan 10(1): 421-424.

\section{How to cite this article:}

Khushdeep Singh, Balwinder Singh Dhillon and Vikram Limba. 2021. Effect of Mulching on Growth and Productivity of Bt Cotton (Gossypium hirsutum L.). Int.J.Curr.Microbiol.App.Sci. 10(01): 2610-2615. doi: https://doi.org/10.20546/ijcmas.2021.1001.304 